Reporting Date: August 1975 Issued: September 1975

\title{
Survival of Cultured Mammalian Cells Irradiated at Various Depths in the LAMPF Negative Pion Therapy Beam
}

by

\author{
P. W. Todd \\ J. Dicello \\ G. West \\ C. Shonk
}

M. M. Kligermars

M. R. Raju

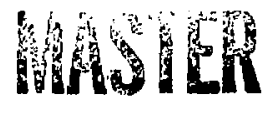

scientific laboralory

of the University of Californio

LOS ALAMOS, NEW MEXICO 87545

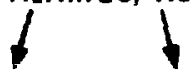

An Alfirmative Action/Equal Opportunity Employer 
In the interest of prompt distribution, this report was not edited by the Technical Information staff.

Work partially supported by U.S. Public Health Service grant No. CA-14052 from the Division of Research Resources and Centers of the National Cancer Institute to the University of New Mexico Cancer Research and Treatment Center.

Printed in the United Strite of Amorica. Available from National Technical Information Service

U S Department of Commerce

5205 Port Royal Road

Springfield, VA 2215!

Price: Printed Copy S4.0U Microticho \$2.25

Thin report wan prepared as an eccount of work aponnored

by the Unlied Sintes Governesent. Neiluar the United Btated

nor the United Bthles Eaeray Research and Developenent Ad-

minintration, nor eny of their espployees, nor any of their con

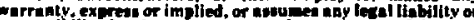

res poneibility for the eccurecy. completeness, of usefulness of

any informution, thparntus, protuct. or process diccioned, or

repreants that its use would not infringe privately owned
riahts. 
This repant was Notice

This repuit was prepated as an acuoume of work the Unit by she Unied Stales Givec noment Neither Reseash ind Ues not the Uriled Stated inergy these employess subcontractors. of then of thest coniracluts. warranty. expiess of impled, or atsumes any any lubility or respanaibility for the accuracy, completeng or useruines of any informulion, appasat us, pioducl or prucess diselored, yt teptesents that is us woutd nut infringe proately uwned rights.

SURVTVAL OF CULTURED MAMMALAN CELLS IRRADIATED AT VARIOUS DEPTHS

IN THE IAMPF NEGATIVE PION THERAPY BEAM

by

P. W. Todd, J. Dicello, G. West, C. Shonk,

M. M. K1Igerman, and M. R. Raju

ABSTRACT

Cultured human kidney $\mathrm{T}-1$ cells were irzadiated in flasks or on coverslips at different depths in a water phantom using the Cilnton P. Anderson Meson Physics Facility (LAMPF) negatjve pion beam. Studies of cell survival and divislon delay as a function of depth and recovery between doses indicate $R B E s$ of $1.8 \pm 0.3$ and an ability of cells to recover between two doses of stopping pions.

\section{MATERIALS AND METHODS}

Human kidney T-1 cells were cultured in Eagle's BME containing $10 \%$ fetal bovine serum and were irradiated while attached to T-2S culture flasks (Falcon Plastics) or coverslips (LUX Plastics). Colony development was illowed to take place without further post-irradiation disturbance of the cells. Survival was determined as previously described. ${ }^{1}$ The configurations of irradiation are shown in Fig. I. For brevity and consistency, the results reported here

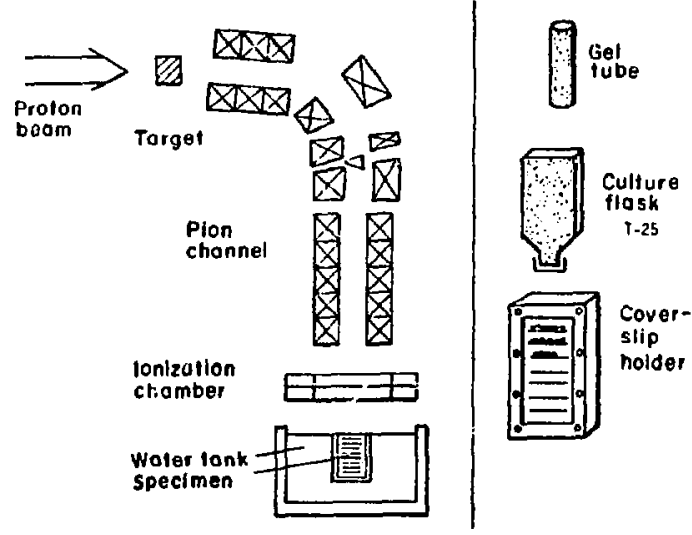

Fig. 1. Irradiation configuration for human $T-1$ cells in flasks and on coverslips. were obtained from experiments in which the cells were irradiated in flasks.

The depth-dose and transverse beam profiles for which blological data are currently available are shown In Fig. 2. The double-beam profile shown in Fig. 3 was also used in the irradiation of coverslip cultures, and the colony-count data are reported elsewhere. 2

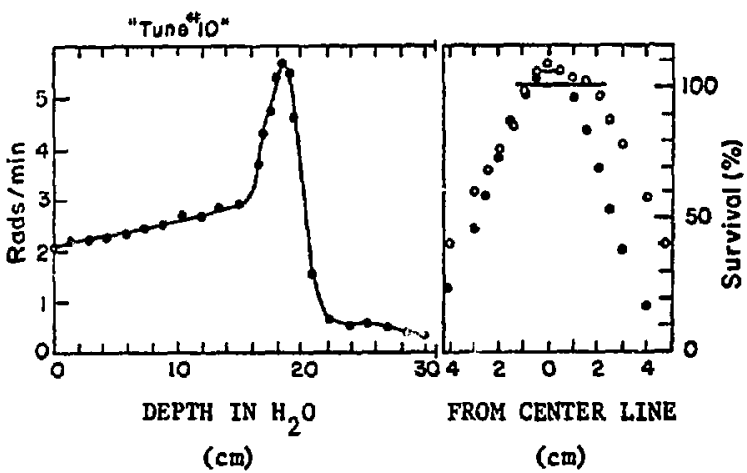

Fig. 2. Depth-dose profile (left) and transverse beam profile ( $r$ ight). The horizontal bars represent ofmensions of the irradiated pairs of flasks in the $x$ and $y$ beam planes. 


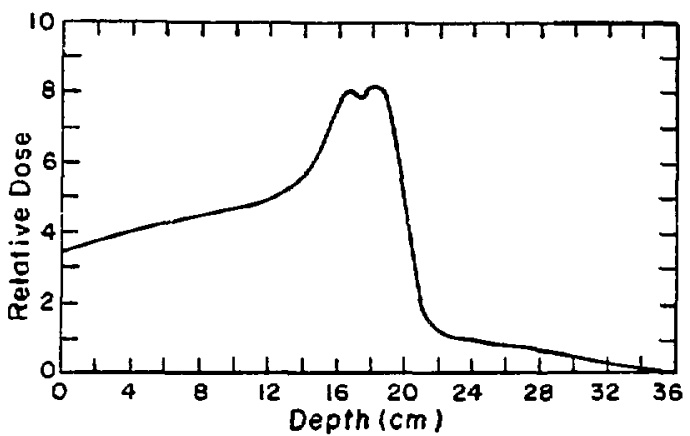

Fig. 3. Depth-dose profile calculated for double Irradiation of cultures by adding $50 \%$ more dose at a $2.5-\mathrm{cm}$ shallower position than the first exposure fused in Irradiation of the coverslip holders to evaluate change in RBE through the modulated peak).

\section{RESULTS}

Figure 4 shows the results of experiment 800 in which cells in flasks were irradiated with 100 rads (bottom panel) and 200 rads (top panel) of negative pions at the position of maximum dose (in the profile of Fig. 2). In this experiment, an aluminum oxide target was employed for pion production, and the peak dose rate occasionally reached $6 \mathrm{rads} / \mathrm{min}$.

In experiment 801, cells of another cell line were used (ChInese hamster M3-1), as this celi line is more resistant than $T-1$ cells to both $h i g h-$ and low-LeT radiations. ${ }^{3}$ Figure 5 , which shows the

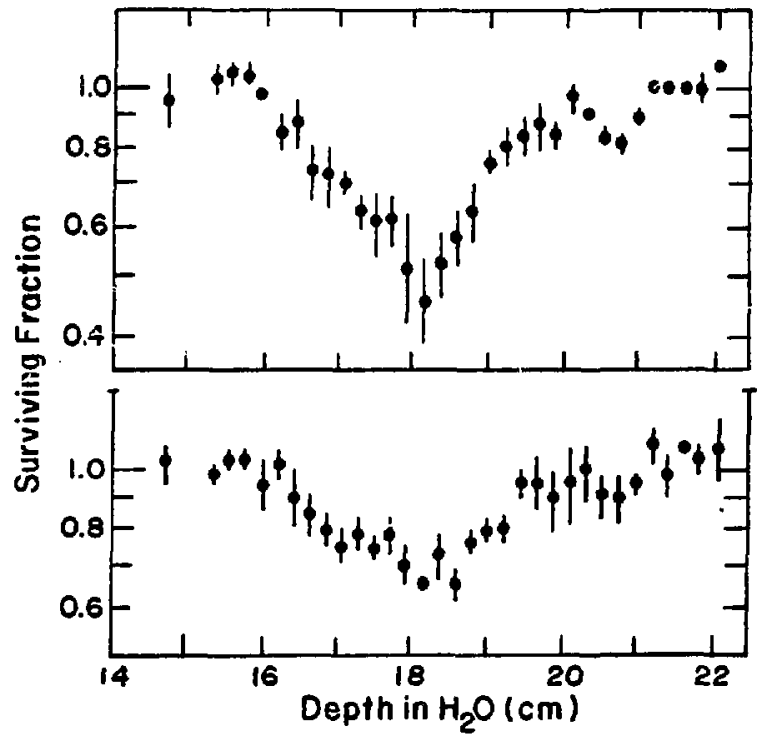

F1g. 4. Depth-survival profile for cultured human I- 1 cells irradiated in flasks with 200 peak rads pions (top) and 100 rads (bottom).

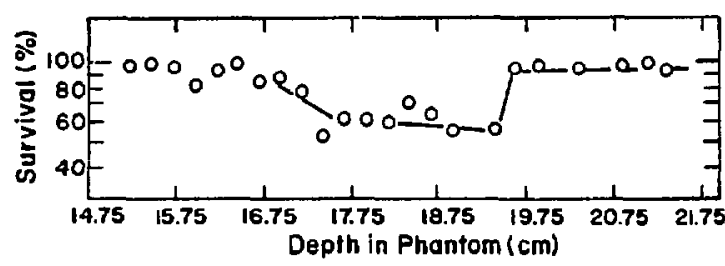

Fig. 5. Dopth-survival profile for cultured Chinese hamster M3-1 cells 1rradiated in flasks with 200 peak rads plons.

depth-survival profile for these cells, Indicates that they are also resistant to stopping pions. Although the dose peak occurred at a depth of 18.4 to $18.7 \mathrm{~cm}$, this figure also indicates a rather flat survival profile all the way back to $19.6 \mathrm{~cm}$. The lethality peak is expected to be broader than the dose peak because the dose-average LET (and hence the biological effect) is greater beyond the depth at which the maximum dose accurs.

This blological broadening of the dose peak is also suggested in FIg. 6 which presents a portion of the regults of experiment 820 . This experiment was a repeat of the above experiments with T-1 cells, but a carbon target was used for pion production, and the average dose rate tended to be around $3 \mathrm{rads} / \mathrm{min}$ at the dose peak (located 18.4 to $18.7 \mathrm{~cm}$ into the water phantom). Survival was very nearly constant over a breadth of $\sim 1 \mathrm{~cm}$ at the doses used $(100,200$, 300 , and 400 rads). In addition, a fractionated exposure was made in which a set of cultures recelved 400 rads in four 100-rad fractions delivered exactiy every $3 \mathrm{~h}$.

Dose-response curves were generated from the data of experiments 800 and 820 using doses and survivals at $18.75 \mathrm{~cm}$ depth, and these are plotted in F1g. 7 along with an estimate of the $x$-ray survival

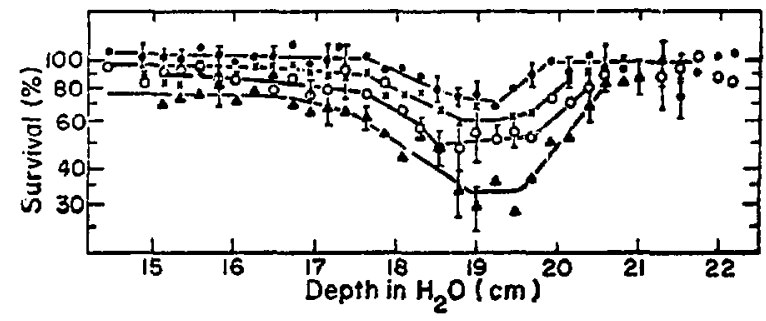

F1g. 6. Depth-survival profiles for human $T-1$ cells irradiated with $100(-0-), 200(-X-), 300$ $(-0-)$, and $400(-1-)$ peak rads pions. 


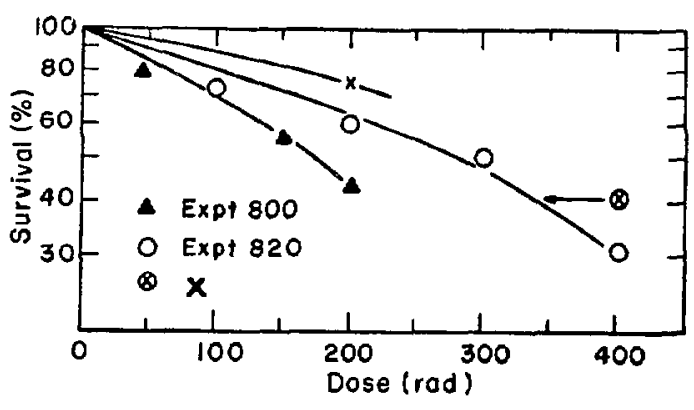

Fig. 7. Dose-survival curves derived from Figs. 3 and 5 compared with $x$-ray survival $(-x-)$ and with survival of cells receiving 400 rads as four $100-r a d$ treatments every 3 h $(-\otimes-)$.

curve under the same conditions at jow doses and at acute dose rates. At the higher pion doses, the survival curve of experiment 800 (F18. 4) lies below that of the later experiment (F1g. 6). It is possible that this difference is due to a dose-rate effect. In the region of 100 peak pion rads, the two curves do not differ significantly. Comparing the combined curves to cell survival following a 200-rad dose of $x$ rays $y$ lelds an average relative biological effectiveness (RBE) of $1.8 \pm 0.2$. The error limits on this iigure are still too broad for serious clinical application. The cells that received 400 rads in 100-rad increments survived as if they had received 340 rads in a single dose. Therefore, the existence of a small amount of sublethal damage repair following pion irradiation in this dose range is apparent.

Additional end points studied included postirradiation growth. The scoring of rells per colony

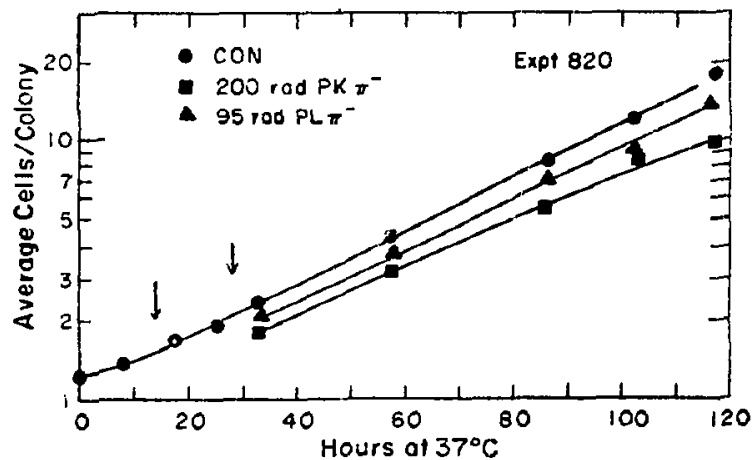

Fig. 8. Post-irradjetion growth curves for human T-1 cells exposed to plons in the peak and plateau regions. by phase-contrast microscopy of the firadiated cultures yielded the growth curves of F1g. 8. The division delay per rad appeared to be very nearly the same at the two positions studied.

\section{DISCUSSION}

A single frradiation with 100 rads of peak pions does not appear to kill any cells in the plateau portion of the depth-dose profile. This may not be true in the case of daily 100-rad fractions, and $1:$ would need to be tested in an in vivo system. A 10 to $15 \%$ reduction in cell survival in the plateau region occurred after four 100-rad fractions were delivered at the peak; however, in this case, only $3 \mathrm{~h}$ intervened between exposures.

An unmodulated beam should be adequate for $1 \mathrm{r}-$ radiating a $1-\mathrm{cm}$ treatment volume, and two overlapping peaks may be adequate for treating a $4-\mathrm{cm}$ treatment volume to a uniform dose. Biological results to date are consistent with this conclusion.

The downward curvature of the survival curves 1mplies that some pion damage is sublethal and must be accumulated. The fractionation experiment suggests that this sublethal damage can be repaired. When these preliminary data are used to determine the exponent of $N$ (the number of daily fractions) In the "ISD" (Nominal Standard Dose) formula, the value of the exponent becomes 0.11 , similar to that determined for neutrons used for radiotherapy at the Texas $A$ and $M$ University cyclotron (TAMVEC) but greater than $\sim 0.04$ estimated for the Hammersmith Hospital ${ }^{4}$ and the Naval Research Laboratory ${ }^{5}$ neu* trons. In neutron experiments, no evidence has indicated that the exponent of $T$ (the time over which treatment is administered) should change, 4,5 and pion experiments with synchronous cells to investigate division delay and ocher nonlethal effects are needed. $D=N S D \times N^{0.11} \times T^{0.11}$ can be used as an initial estimate of the time-dose relationship for stopping pions in the configuration used in these experiments. In other words, the Kligerman formula, $D=S D \mathrm{~T}^{0.33}$, for dafly irradiations, would become $D=S D \times T^{0.22}$.

An analysis of the data presented here is still incomplete. For example, a thorough consideration of the higher RBE on the "back" side of the close peak has yet to be made. An RBE in the vicinity of 2.0 can perhaps be anticipated. 
The blological action of pions in the peak of this beam configuration may or may not resemble that of TAMVEC neutrons. It may b? worthwhile to explore other factors than RBE and fractionation to deterwine to what extent such a resemblance exists. Experiments determining the fractionation response of mouse jefunal crypts and the OER for Vicia faba root growth Inhibition, both of which have been done very well at TAMVE, may make an entire set of parameters from the TAMVEC experience avallable to the LAMPF pion program.

An Initial estimate of the equivalent of $200 \mathrm{x}-$ ray rads dally for 7 wh was made from the results of this study. It appears that approximately 120 rads of peak pions per day on the same schedule would lead to the same level of cell lethallty.

\section{RE FERENCES}

1. P. Todd, "Heavy Ion Irradiation of Cultured Yuman Cells," Radiation Res. Suppl. 7, 196-20? (1967).

2. P. Todd, G. West, C. Shonk, J. Dicello, and M. K. Kligerman, "Spattal Distribution of Culcured Human Cell Survivai in a Negative Pi Meson Beam," Radiology 116, 179-182 (1975).

3. P. Todd, "Heavy-Ion I rradiation of Human aist Chinese Hamster Cells in Vitro," Radlarion Res. $61,288-297$ (1975).

4. S. B. Field, "The Ellis Formulae for X-rays and Fast Neutrons," Br1t. J. Radiol. 45, 315 (1972).

5. P. Todd, C. B. Schroy, F. H. Att $1 X$, and R. B. Theus, "Fractionated I rradiation of Cultured Human Cells with Therapeutic Doses of Fast Neutrons," Radiation Res. 59, 123-124 (1974). 